\title{
Lymphocyte and Neutrophil to Lymphocyte Ratio do not Predict Mortality in Hip Fracture Patients
}

\author{
DAN VASILE POP¹, CRISTINA VLAD DALIBORCA2*, DANIELA RADU³, DINU VERMESAN¹, BOGDAN DELEANU1, \\ AHMED ABU AWWAD ${ }^{1}$, ADRIAN TODOR ${ }^{4}$ \\ ${ }^{1}$ Victor Babes University of Medicine and Pharmacy, Department of Orthopedics and Trauma, 2 Eftimie Murgu Sq., 300041, \\ Timisoara, Romania \\ ${ }^{2}$ Victor Babes University of Medicine and Pharmacy, Department of Pharmacology, 2 Eftimie Murgu Sq., 300041, Timisoara, \\ Romania \\ ${ }^{3}$ Victor Babes University of Medicine and Pharmacy, Department of Surgery, 2 Eftimie Murgu Sq., 300041, Timisoara, Romania \\ ${ }^{4}$ Iuliu Hatieganu University of Medicine and Pharmacy, Department of Orthopedics, Traumatology and Pediatric Orthopedics, 8 \\ Victor Babes Str.,400012, Cluj Napoca, Romania
}

Ourstudyaimed to assess whether admission hemoglobin, lymphocyte count and neutrophil to lymphocyte ratio (N/R) can predict 1-year survival in patients with hip fractures. In the study, data from 54 patients with femoral neck fractures, 119 with trochanteric fractures respectively 24 with subtrochanteric fractures was analyzed. All the included patients were older than 55 years and were followed up to 2 years or until the decease occurred. The following parameters were recorded in patients with femoral neck, trochanteric respectively subtrochanteric fractures: average age: 76; 79.7 respectively 73.3 years; male to female ratio: 1:2.86; 1:3.1 respectively 1:2; average hemoglobin at admission: 13.13, 11.56 respectively 11.81; average lymphocyte count: 1.69; 1.7 respectively 1.75. At the logistic regression model built having the death as outcome and the lymphocytes respectively the $N / L$ as predictors, we did notfound any significantassociations in neither of the groups ( $p$ values of $0.837,0.171$ and 0.162 for lymphocyte and $0.920,0.764$ and 0.168 for $N$ / $L$ respectively). When age, gender and hemoglobin at admittance were accounted for, only for fractures of the trochanteric region age was predictive of survival with $p<0.001$. Our study showed no prediction for survival of hip fracture patients by using perioperatively collected total lymphocyte count and neutrophil to lymphocyte ratio.

Keywords: hip fracture; femoral neck; survival; lymphocyte; neutrophil to lymphocyte ratio

Hip fractures are a major social and healthcare burden. Theyoccur in elderly frail population and have high mortality $[1,2]$.

Several factors have been shown to be predictive of outcome, such as age, male gender, extracapsular fracture, delay of surgery, comorbidities and nutritional status. Routine blood tests are readily available for preoperative planning and have been shown to be predictive for cancer and cardiovascular events outcome [3,4].

In hip fracture patients there is some evidence that several simple laboratory markers could predict survival $[5,6]$.

However, parameters may show heterogeneity in different populations and geographic areas [1,2,5-8] .

We aimed to determine whether admission hemoglobin, lymphocyte count and neutrophil to lymphocyte ratio can predict 1-year survival after hip fracture patients.

\section{Experimental part}

We performed a retrospective, single center observational study of with prospectively collected data for survival. Hip fracture patients over 55 years old admitted for surgical treatment over 9 months (Oct.2015 to Jun.2016) were scrutinized. Electronic charts were subsequently reviewed by two authors. 197 patients were included for analysis. Those who did not undergo surgical treatment, had total arthroplasty or extramedullary fixation were excluded. Age, gender, hemoglobin, neutrophil and lymphocyte at admittance and type of surgical treatment were recorded in Excel (Microsoft Office 10). Hematology panel was determined using ADVIA 2120 flow cytometry and spectrophotometry. Patients were then prospectively followed up until Oct.2017 (1.25-2 years) when survival status was retrieved. The study was approved by the Hospital's Ethics Committee and Research department.

To assess the association between the studied parameters and the risk of death, we built logistic regression models in which the outcome was considered the death event, while the different parameters from the study were considered possible predictors.

\section{Results and discussions}

We included 54 femoral neck fractures, 119 fractures of the trochanteric region and 24 subtrochanteric. The displaced femoral neck fractures were treated using press fit hemiarthroplasty (Biomet, Warsaw, USA) through a lateral approach. For extracapsular fractures internal fixation was performed using standard or long Gamma3 nails (Stryker, USA). Surgical techniques adhered to the manufacturer's recommendations and were performed under regional anesthesia (spinal, epidural or combined spinal-epidural). Comparative demographic data is presented in table 1.

Influence of lymphocyte and neutrophil to lymphocyte ratio $(\mathrm{N} / \mathrm{L})$ was determined in each of the 3 groups as well as overall. For the femoral neck fractures, fractures of the trochanteric and subtrochanteric region respectively, the associations from the logistic regression model proved to be not significant, with $p$ values of $0.837,0.181$ and 0.162 for lymphocyte and $0.920,0.794$ and 0.168 for N/L respectively (Table 2 ). When age, gender and hemoglobin 


\begin{tabular}{|l|l|l|l|l|l|l|l|}
\hline Fracture type & $\mathrm{N}$ & $\begin{array}{l}\text { Age } \\
\text { (average) }\end{array}$ & Male: Female & Hb & Ly & Neutro & Survival \\
\hline Femoral neck & 54 & 76 & $1: 2.86$ & 13.13 & 1.69 & 8.21 & $83.3 \%$ \\
\hline $\begin{array}{l}\text { Trochanteric } \\
\text { region }\end{array}$ & 119 & 79.7 & $1: 3.1$ & 11.56 & 1.7 & 9.19 & $67.2 \%$ \\
\hline Subtrochanteric & 24 & 73.7 & $1: 2$ & 11.81 & 1.75 & 8.69 & $83.3 \%$ \\
\hline
\end{tabular}

Table 1

DEMOGRAPHIC DATA. Hb HEMOGLOBIN, LY - LYMPHOCYTE AND NEUTRO - NEUTROPHILS AT ADMITTANCE $\left(* 10^{3} / \mu \mathrm{L}\right)$

\begin{tabular}{|l|l|l|l|l|}
\hline & \multicolumn{2}{|c|}{ Lymphocyte count } & \multicolumn{2}{c|}{$\begin{array}{c}\text { Neutrophil to } \\
\text { lymphocyte ratio }\end{array}$} \\
\hline & OR & $\mathrm{p}$ & OR & $\mathrm{p}$ \\
\hline Femoral neck (P) & 0.901 & 0.837 & 1.009 & 0.920 \\
\hline $\begin{array}{l}\text { Trochanteric region } \\
\text { (G) }\end{array}$ & 1.436 & 0.181 & 0.987 & 0.794 \\
\hline Subtrochanteric (L) & 8.174 & 0.162 & 35.89 & 0.739 \\
\hline
\end{tabular}

Table 2

INFLUENCE OF LYMPHOCYTE AND NEUTROPHIL TO LYMPHOCYTE RATIO (N/L) DETERMINED FROM THE LOGISTIC REGRESSION MODEL at admittance were accounted for, only for the fractures of the trochanteric region age was an independent predictor of survival with $p<0.001$.

In our study, the absolute lymphocyte number as well as $N / L$ were not predictive of survival up to 2 years after surgical treatment of a proximal hip fracture. In addition, neither was hemoglobin at admittance nor male gender. Age was only significant for the subgroup of trochanteric fractures.

These findings differ from some of our previous analysis on survival, as well as other data from the literature $[1,5,6]$.

Laulund et al found several prognostic markers of mortality in hip fracture patients: low hemoglobinat hospital admittance (OR 2.78; $95 \% \mathrm{Cl} 2.17-3.55 ; \mathrm{p}<0.001$ ), low lymphocyte count( OR 2.60; $95 \% \mathrm{Cl} 1.61-4.20$; $p<0.001)$, low albumin (OR 1.83; $95 \% \mathrm{Cl} 1.31-2.56$; $\mathrm{p}<0.001)$, low albumin/low lymphocyte (OR 3.00; $95 \% \mathrm{Cl}$ 1.81-4.99; $p<0.001$ ), low albumin/high lymphocyte (odds ratio, 3.39; 95\% confidence interval, 1.83-6.29; $p<0.001$ ) and high creatinine (OR 1.58; $95 \% \mathrm{Cl} 1.25-1.99 ; \mathrm{p}<0.001$ ). Their research included a much larger cohort than ours, between 704-3761 subjects compared with 197 patients in our study [5].

This might account for the differences in results as well as underline what we consider to be the main weakness of our study. Discrepancies between several studies in the literature are also noted regarding the predictive weight each parameter has.

Mosfeldt et al found a much higher influence of serum creatinine on survival; in their study, mortality in patients with elevated levels of creatinine was three times higher compared with those with values in the normal range. Mortality was also associated with age, low hemoglobin, high plasma potassium, and low plasma albumin levels [9].

Hip fracture patients are generally addressed as subgroup populations. However, treatmentmay sometimes require adjustment from the norms is peculiar cases such as amputations or malignancy $[1,10,12]$.

The ability to obtain prediction of outcome and adverse events from simple, readily available lab values is very tempting. Unlike specialized tests, standard blood count and routine biochemistry are performed for preoperative planning and general assessment [5,11,13,14].
Lymphocyte count is regarded as a marker for energetic malnutrition whereas the neutrophil to lymphocyte ratio is a marker of inflammation $[5,6,15]$.

There might be some value for the $\mathrm{N} / \mathrm{L}$ ratio in knee arthroplasty for osteoarthritis (OA). N/L $\geq 2.1$ emerged as independent predictor indicating severity of knee OA [16].

It has a faster normalization than CRP (C-reactive protein) and thus could represent a potentially better biomarker to follow post-operative inflammation or early infection after total knee replacement [17].

Fracture type, timing of surgery, technique and implant may also ultimately influence outcome but current results are inconsistent [18-20,22].

In addition, other factors also contribute to successful treatment of hip fractures. Large sample research and use of standardized outcome measures such as patient reported outcomes may bring a better way of assessing and predicting postoperative follow up [21,23].

\section{Conclusions}

Our study showed no prediction for survival of hip fracture patients by using perioperatively collected total lymphocyte count and neutrophil to lymphocyte ratio.

\section{Acknowledgements: Med. Student Nageb Dirawi}

\section{References}

1.VERMESAN D, PREJBEANU R, POENARU DV, et al Do intramedullary implants improve survival in elderly patients with trochanteric fractures? A retrospective study. Clin Ter. 2015;166(3):e140-5. doi: 10.7417/T.2015.1844.

2.HARAGUS H, PREJBEANU R, POENARU DV, DELEANU B, TIMAR B, VERMESAN D. Cross-cultural adaptation and validation of a patientreported hip outcome score. Int Orthop. 2018 May;42(5):1001-1006. doi: 10.1007/s00264-017-3742-5.

3.TEMPLETON AJ, MCNAMARA MG, SERUGA B, etal Prognostic role of neutrophil-to-lymphocyte ratio in solid tumors: a systematic review and meta-analysis J Natl Cancer Inst. 2014 May 29;106(6):dju124. doi: 10.1093/jnci/dju124. Print 2014 J un.

4.TAMHANE UU, ANEJ A S, MONTGOMERY D, ROGERS EK, EAGLE KA, GURM HS. Association between admission neutrophil to lymphocyte ratioand outcomes in patients with acute coronary syndrome. Am J Cardiol. 2008 Sep 15;102(6):653-7. doi: 10.1016/j.amjcard.2008.05.006. 
5.LAULUND AS, LAURITZEN JB, DUUS BR, MOSFELDT M, J ØRGENSEN $\mathrm{HL}$. Routine blood tests as predictors of mortality in hip fracture patients. Injury. 2012 Jul;43(7):1014-20. doi: 10.1016/j.injury.2011.12.008. 6.FORGET P, MOREAU N, ENGEL $H$, CORNU O, BOLAND B, DE KOCK $M, Y O M B I J C$. The neutrophil-to-lymphocyte ratio (NLR) after surgery for hip fracture (HF). Arch GerontolGeriatr. 2015 Mar-Apr;60(2):366-71. 7.HARAGUS, H., PREJ BEANU, R., TIMAR, B., VERMESAN, D., A-mode ultrasound analysis of postoperative thigh edema in patients with hip fracture Mat.Plast, 54, no. 3, 2017, p.553

8.MIOC ML, PREJBEANU R, DELEANU B, ANGLITOIU B, HARAGUS H, NICULESCU M.Extra-articular distal tibia fractures-controversies regarding treatment options. A single-centre prospective comparative study. Int Orthop. 2018 Apr;42(4):915-919. doi: 10.1007/s00264-018-37754.

9.MOSFELDT M, PEDERSEN OB, RIIS T, WORM HO, MARK SV, JORGENSEN HL, DUUS BR, LAURITZEN JB. Value of routine blood tests for prediction of mortality risk in hip fracture patients. ActaOrthop. 2012 Feb;83(1):31-5. doi: 10.3109/17453674.2011.652883.

10.VERMESAN, D., PREJ BEANU, R., HARAGUS, H., NICULESCU, M., Similar Short Term Outcomes with Press-fit Bipolar Hemiarthroplasty and Cemented Total Hip Replacements in Femoral Neck Fractures Mat.Plast.,54, no. 2 , 2017, p. 262-265

11.VERMESAN D, PREJBEANU R, HARAGUS $H$, et al. Case series of patients with pathological dyaphiseal fractures from metastatic bone disease. IntOrthop. 2017 Oct;41(10):2199-2203. doi: 10.1007/s00264-0173582-3.

12.RAMADANI F, HARAGUS H, PREJ BEANU R, TRIEB K, HOFSTAETTER S. [Complex reconstruction with internal locking plate fixation for Charcot arthropathy.] Orthopade. 2015 Jan;44(1):33-8 doi: 10.1007/ s00132-014-3061-0

13.VLAD, C.S., DUMITRASCU, V., VLAD-DALIBORCA, C., et al. Fast and Simple Method for Simultaneous Detection and Quantification of Diazepam and Desmethyldiazepam in Plasma Samples in Psychiatric Patients by GC-MS-FID, Rev.Chim.(Bucharest), 68, 2017, p.530-533 14.ALEXANDRU L, HARAGUS H, DELEANU B, TIMAR B, POENARU DV, VLAD-DALIBORCA C. Hematology panel biomarkers for humeral, femur and tibia diaphyseal fractures Int Orthop. 2019
15.VLAD, C.S., DUMITRASCU, V., VLAD-DALIBORCA, C., et al. Effects of Materials Based on Acrylic Resines on Inflammatory Markers IL-8 and TGF beta 1 in Gingival Crevicular Fluid Mat.Plast., 55 , no.3, 2018, p. 111-114

16.TATODLU 0, BOLÜK H, TAHINONAT T, TATODLU Y, ÖZGIRGIN N. Is blood neutrophil-lymphocyte ratio an independent predictor of knee osteoarthritis severity? ClinRheumatol. 2016 Jun;35(6):1579-83. doi: 10.1007/s10067-016-3170-8.

17.YOMBI JC, SCHWAB PE, THIENPONT E. Neutrophil-to-lymphocyte ratio (NLR) distribution shows a better kinetic pattern than C-reactive protein distribution for the follow-up of early inflammation after total knee arthroplasty. Knee Surg Sports TraumatolArthrosc. 2016 Oct;24(10):3287-3292.

18.TODOR A, CATEREV S, NISTOR DV, KHALLOUKI Y. Free Bone Plug Quadriceps Tendon Harvest and Suspensory Button Attachment for Anterior Cruciate Ligament Reconstruction. Arthrosc Tech. 2016 May 30;5(3):e541-4. doi: 10.1016/j.eats.2016.02.001.

19.CATEREV S, NISTOR DV, TODORA. Anatomic Double-Bundle Anterior Cruciate Ligament Reconstruction With a Free Quadriceps Tendon Autograft. Arthrosc Tech. 2016 Sep 19;5(5):e1063-e1067.

20.DAVID VL, CERBU S, HARAGUS H, POPOIU MC, STANCIULESCU

CM, COZMA G, BURLACU O, BOIA ES. Costal Cartilages Do Not Overgrow in Patients with Pectus Excavatum. Med Princ Pract. 2016;25(6):533-538.

21. HARAGUS $H$, PREJ BEANU R, PATRASCU J, FAUR C, ROMAN M, MELINTE R, TIMAR B, CODOREAN I, STETSON W, MARRA G. CrOSScultural adaptation and validation of the Romanian Oxford Shoulder Score. Medicine (Baltimore). 2018 J un;97(23):e10926. doi: 10.1097/ MD. 0000000000010926

22.ABU AWWAD. A., PREJ BEANU, R., VERMESAN, D., DELEANU, B., IONITESCU, M., FLORESCU, S., Dose effect of local Bethamethasone injection in low back pain. Rev. Chim. (Bucharest), 69, no 9, 2018, p. 2382

23.ABU AWWAD A.., PREJBEANU, R., VERMESAN, D., BRANEA, I., DELEANU, B., FLORESCU, S., VLAD-DALIBORCA, C., Blood Loss of Pedicle Subtraction Osteotomy for Sagittal Imbalance Spinal Deformity. Rev. Chim. (Bucharest), 69, no. 12, 2018, p. 3680

$\overline{\text { Manuscript received: } 9.12 .2018}$ 